\title{
BMP signaling mediated by ALK2 in the visceral endoderm is necessary for the generation of primordial germ cells in the mouse embryo
}

\author{
Susana M. Chuva de Sousa Lopes, ${ }^{1}$ Bernard A.J. Roelen, ${ }^{2,3,5,6}$ Rui M. Monteiro, ${ }^{1}$ Roul Emmens, ${ }^{1}$ \\ Herbert Y. Lin, ${ }^{2,3,5}$ En Li $^{4,5,7}$ Kirstie A. Lawson, ${ }^{1}$ and Christine L. Mummery ${ }^{1,8}$ \\ ${ }^{1}$ Hubrecht Laboratory, Netherlands Institute for Developmental Biology, Uppsalalaan 8, 3584 CT Utrecht, The Netherlands; \\ ${ }^{2}$ Program in Membrane Biology, ${ }^{3}$ Renal Unit, and ${ }^{4}$ Cardiovascular Research Center, Massachusetts General Hospital, \\ Charlestown, Massachusetts 02129, USA; ${ }^{5}$ Department of Medicine, Harvard Medical School, \\ Charlestown, Massachusetts 02129, USA
}

Deletion of various bone morphogenetic proteins (BMPs) and their downstream Smads in mice have clearly shown that BMP signaling is essential for the formation of primordial germ cells (PGCs). However, the molecular mechanism through which this takes place is still unclear. Here, we demonstrate that BMP4 produced in the extraembryonic ectoderm signals through ALK2, a type I BMP receptor, in the visceral endoderm (VE) to induce formation of PGCs from the epiblast. Firstly, embryonic day 5.5-6.0 (E5.5-E6.0) embryos cultured on fibronectin formed PGCs in the presence of VE, but not in its absence. Secondly, Alk2-deficient embryos completely lacked PGCs and the heterozygotes had reduced numbers, resembling Bmp4-deficient phenotypes. Thirdly, expression of constitutively active ALK2 in the VE, but not in the epiblast, was sufficient to rescue the PGC phenotype in Bmp4-deficient embryos. In addition, we show that the requirement for the VE at E5.5-E6.0 can be replaced by culturing embryos stripped of VE on STO cells, indicating that STO cells provide or transduce signals necessary for PGC formation that are normally transmitted by the VE. We propose a model in which direct signaling to proximal epiblast is supplemented by an obligatory indirect BMP-dependent signal via the VE.

[Keywords: Primordial germ cells; mouse; embryo; visceral endoderm; ALK2; BMP signaling]

Received December 5, 2003; revised version accepted May 21, 2004.

In most metazoa, the development of primordial germ cells (PGCs) is crucial for the survival of the species, because these are the cells that form the gametes that transmit the genetic material to future generations. In species such as Drosophila, Caenorhabditis elegans, Xenopus, zebrafish, and chick, the PGC lineage can be followed from the egg or the two-cell stage onward because of the segregation of germ-cell determinants (for review, see McLaren 2003). In contrast, in the mouse only at embryonic day 7.2 (E7.2) does a founding population of $\sim 45$ cells descendent from E6.2-E6.5 proximal epiblast (embryonic ectoderm) cells become lineage-restricted to the germ line (Lawson and Hage 1994). More-

Present addresses: ${ }^{6}$ Department of Farm Animal Health, Faculty of Veterinary Medicine, Utrecht University, 3584CL Utrecht, The Netherlands; ${ }^{7}$ Models of Disease Center, Novartis Institute for Biomedical Research, 100 Technology Square, Cambridge, MA 02139, USA. ${ }^{8}$ Corresponding author.

E-MAIL christin@niob.knaw.nl; FAX 31-30-2516464.

Article and publication are at http://www.genesdev.org/cgi/doi/10.1101/ gad.294004. over, at E6.5, both proximal and distal epiblast cells are still competent to become PGCs if positioned posteriorly in the proximal epiblast (Tam and Zhou 1996; Yoshimizu et al. 2001). Interestingly, although allocated by different mechanisms, the PGC lineage is probably the first exclusively embryonic lineage to be established in the mouse as it is also in the other species mentioned.

To date, the repertoire of signals involved in PGC induction has only been identified in part. Lawson et al. (1999) demonstrated that the signal transduction cascade activated by bone morphogenetic protein 4 (BMP4) produced by the extraembryonic ectoderm (ExE) is necessary for the generation of PGCs and allantois. In addition, other BMPs (BMP8b and BMP2) have been shown to be of importance for establishing normal numbers of PGCs (Ying et al. 2000; Ying and Zhao 2001). Recently, Ifitm3 (also known as Fragilis or mil-1) was detected in the proximal epiblast at E6.25-E6.5 (Saitou et al. 2002; Tanaka and Matsui 2002), where progenitors of PGCs (among others) are located (Lawson and Hage 1994). Strikingly, Ifitm3 is down-regulated in Bmp4-deficient 
embryos (Saitou et al. 2002) and may thus be involved in the specification of germ cells, although this is currently unclear.

BMPs belong to the TGF $\beta$ superfamily of secreted growth factors. At the cell surface of target cells, BMP dimers bind type I (activin receptor-like kinase; ALK2, ALK3, or ALK6) and type II (BMPR-II, ActR-IIA, or ActRIIB) BMP receptors forming heteromeric complexes. The type II BMP receptor phosphorylates the type I BMP receptor, allowing it to phosphorylate the BMP receptorregulated Smads (Smad1, Smad5, or Smad8). Upon activation, these Smads bind to Smad4 and translocate from the cytoplasm to the nucleus, where they regulate transcription of BMP target genes (for a detailed review, see Shi and Massagué 2003).

Using gene ablation in mice, Smad1 and Smad5 have been described as important for induction of PGCs (Chang and Matzuk 2001; Tremblay et al. 2001; Hayashi et al. 2002). Embryos lacking BmpRII or ActR-IIA ${ }^{-1-}$; $A c t R-I I B^{-1-}$ double homozygotes entirely fail to form mesoderm, whereas single mutants for ActR-IIA or ActR-IIB, although exhibiting several defects, develop to term (Matzuk et al. 1995; Oh and Li 1997; Song et al. 1999; Beppu et al. 2000). All three known type I BMP receptors have been deleted in mice, but only Alk2 and Alk3 mutants exhibit an embryonic lethal phenotype (Mishina et al. 1995, 1999; Gu et al. 1999; Yi et al. 2000). Alk3-deficient embryos, like BmpRII-deficient embryos, implant and form a proamniotic cavity but fail to gastrulate, whereas Alk2 (also known as Acvr1, ActRIA, or Tsk-7L) deficient mice are arrested slightly later in development. The Alk2 mutation shows incomplete penetrance, and some Alk2 homozygotes generate embryonic mesoderm, although extraembryonic mesoderm, particularly the allantois, is never observed. This is reminiscent of the Bmp4 mutant phenotype on some genetic backgrounds (Winnier et al. 1995). In addition, Alk2 homozygous embryos show abnormal visceral endoderm (VE) with a visible constriction at the embryonic-extra- embryonic boundary. ALK2 mRNA was detected at E6.0 by RT-PCR (Roelen et al. 1994), and ALK2 was detected at E6.5 by immunofluorescence primarily in the VE $/ \mathrm{Gu}$ et al. 1999).

Although BMPs produced by the extraembryonic tissues are required for PGC formation, there is no evidence that BMPs signal directly or exclusively to the proximal epiblast cells to induce several of them to become PGCs. Here, we show that there is an absolute requirement for ALK2 in the VE at E5.5-E6.0 for PGC formation to take place: absence of VE in explants (cultured embryos) or ALK2 in embryos results in the complete absence of PGCs, mimicking the Bmp4 mutant phenotype, whereas PGC formation in explants from Bmp4 mutant embryos can be rescued by constitutively active ALK2, but only in the presence of VE. Therefore, we suggest that BMP4 signals through ALK2 in the VE to induce formation of PGCs from the epiblast. Furthermore, we demonstrate that the reason for inconsistent reports in the past on whether or not VE is required for PGC formation is the consequence of different substrata used for explant cultures: STO feeder cells have the ability to induce PGCs to form in embryos stripped of VE at E5.5-E6.0, but in similar experiments using fibronectin substrata, no PGCs form, demonstrating an absolute requirement for $\mathrm{VE}$ at this stage.

\section{Results}

BMP signaling in proximal epiblast and VE during early postimplantation mouse development

Before gastrulation, BMP signaling was detected in cells of the proximal epiblast (Fig. 1A-C) using an antibody that specifically recognizes the active (C-terminal phosphorylated) form of the BMP receptor-regulated Smads (PS1/5/8; Persson et al. 1998), suggesting that BMPs from the ExE signal directly to epiblast cells. In addition, as early as E5.5, cells of the VE also exhibited distinctive
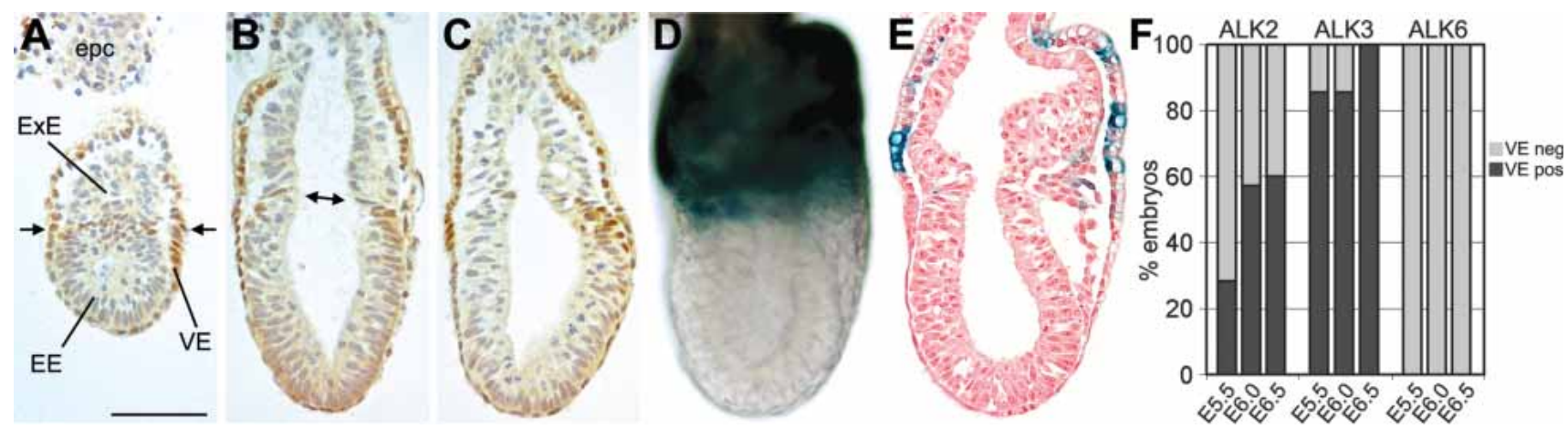

Figure 1. BMP signaling and expression of BMP type I receptors in early postimplantation mouse embryos. $(A-C)$ Activated $(\mathrm{C}$ terminal phosphorylated) BMP receptor-regulated Smads were detected by immunohistochemistry in the VE and proximal epiblast (arrow) of E5.5 $(A)$, E6.0 $(B)$, and E6.25 $(C)$ embryos. $(D, E)$ Whole mount $(D)$ and section $(E)$ of E6.5 BRE:LacZ transgenic embryos. (EE) Epiblast; (epc) ectoplacental cone; (ExE) extraembryonic ectoderm; (VE) visceral endoderm. Bar, $50 \mu \mathrm{m}$. $(F)$ Percentage of embryos $(\%$ embryos) expressing mRNA for the different BMP type I receptors, ALK2, ALK3, and ALK6 in isolated VE at E5.5 ( $n=7)$, E6.0 ( $n=7)$, and E6.5 ( $n=5)$ using RT-PCR. The primer combinations used had similar sensitivities (data not shown). GAPDH mRNA was detected in all samples, confirming that RNA isolation and reverse transcription were successful (data not shown). 
nuclear PS1/5/8 expression (Fig. 1A-C), in particular, surrounding both the ExE and proximal epiblast. The staining observed distally both in the epiblast and VE is nonspecific as confirmed by the (nonreagent) negative control (data not shown). In agreement, analysis of E6.5 $B R E: L a c Z$ transgenic embryos, containing a BMP-responsive element coupled to LacZ (Monteiro et al. 2004) indicated that activation of the BMP signaling pathway, indeed, occurred in the VE surrounding both the ExE and proximal epiblast, and in cells, derived from proximal epiblast that ingressed through the most posterior part of the primitive streak (Fig. 1D,E). To determine which type I BMP receptors mediated the observed activation of BMP signaling in the VE during early postimplantation stages, we performed RT-PCR on VE isolated from E5.5, E6.0, and E6.5 embryos. ALK2 and ALK3 mRNA, but not ALK6 mRNA, was detected in the VE at all stages analyzed (Fig. 1F), whereas all three type I BMP receptors were detected in embryos with the VE removed at E5.5, E6.0, and E6.5 (data not shown).

\section{The VE is necessary for induction of PGC formation} at E5.5-E6.0

Even though PGCs are not the only cell population in embryos or explants (cultured embryos) exhibiting alkaline phosphatase (AP) activity, their typical morphology and AP staining pattern, in particular at the cell surface, and the characteristic dark cytoplasmic "spot", allowed us to identify them clearly and unambiguously as PGCs (Chiquoine 1954; Ginsburg et al. 1990). Independent confirmation of their identity was nevertheless obtained. Using Oct4DPE:gfp transgenic embryos (Yeom et al. 1996), we showed that the majority of the AP-positive cells ( $90 \%)$ identified as PGCs coexpressed Oct4 (driven by its distal promoter element) and/or PGC7/Stella (Saitou et al. 2002; Sato et al. 2002), both independent PGC markers (Fig. 2A-C). Furthermore, clusters of intensely AP-positive cells coexpressed GFP in Oct4DPE:gfp explants (data not shown), and such clusters were therefore also regarded as PGCs.

The observation that there was BMP signaling in the VE during early postimplantation development led us to investigate the role of the VE in the induction of PGCs. We cultured E5.5-E6.5 embryos either intact or with the VE removed (but retaining the ExE) on coverslips coated either with fibroblast feeder cells (STO/SNL cells) or with fibronectin (FN) and subsequently analyzed the explants for AP activity (Fig. 2D-I). Explants derived from E6.5 embryos did not require either VE or feeder cells, and the majority of the VE-stripped embryos $(\geq 80 \%)$ formed PGCs (Fig. 2D-G), although their number was significantly lower than the number of PGCs in explants derived from intact embryos (Fig. 2D,E).

We observed that when cultured on STO cells, explants derived from E5.5-E6.0 embryos did, indeed, generate AP-positive PGCs, even when stripped of VE (Fig. 2D). Moreover, although the number of PGCs in the explants was variable, both intact and VE-stripped embryonic explants developed similar numbers of PGCs in cul-
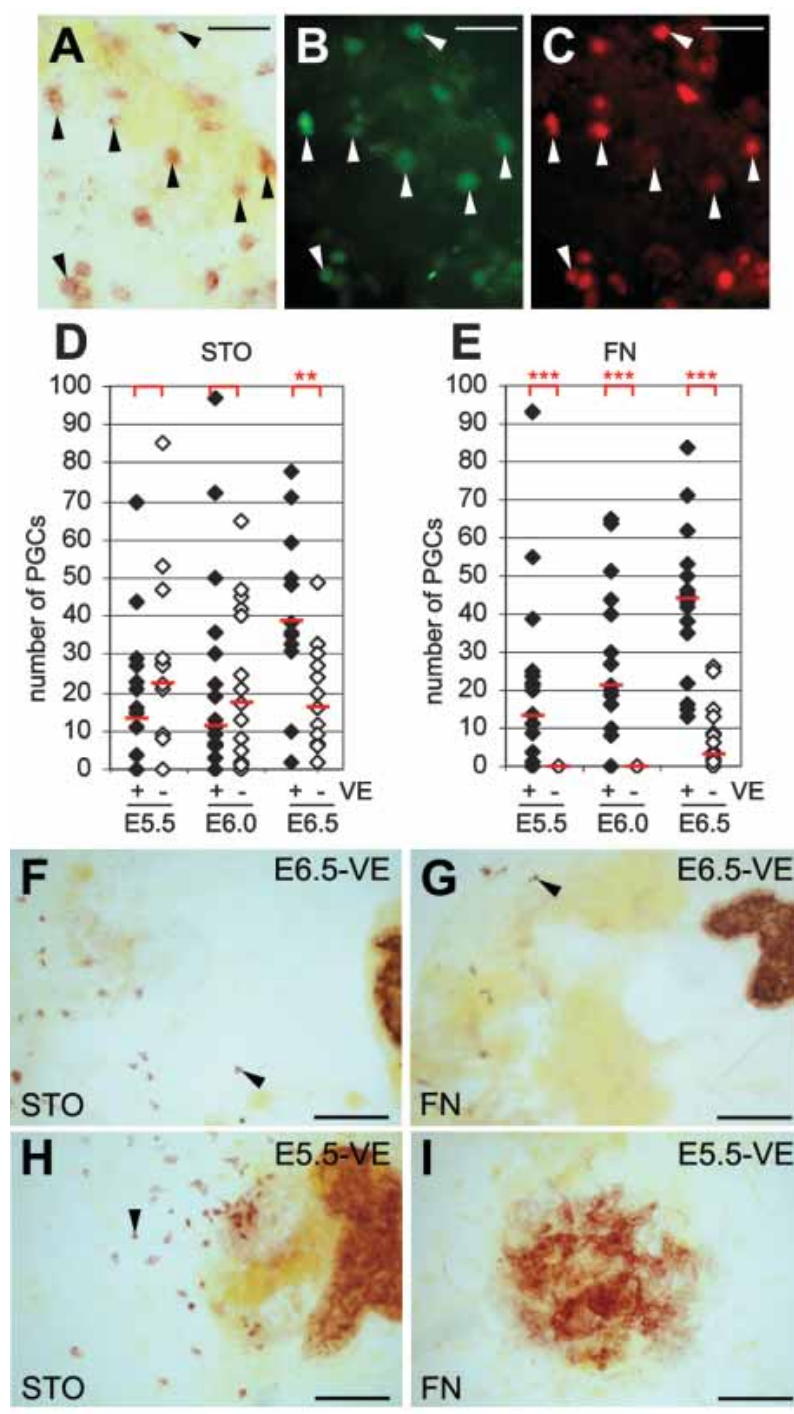

$6.5-\mathrm{VE}$

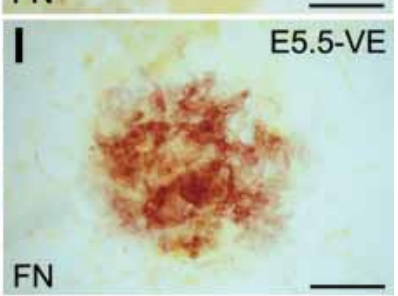

Figure 2. Formation of PGCs after culture of E5.5-E6.5 embryos either on STO cells or fibronectin. $(A-C)$ Most AP-positive cells identified as PGCs $(A)$, coexpressed Oct4 $(B)$, and PGC7/Stella $(C)$ as demonstrated for Oct4 $\triangle P E: g f p$ heterozygous E6.0 embryos cultured without VE on STO cells. PGCs are indicated by arrowheads. Bar, $40 \mu \mathrm{m}$. (D) Numbers of PGCs detected in explants derived from intact or VE-stripped E5.5-E6.5 embryos $(n=15-19)$ cultured on STO cells. (E) Numbers of PGCs detected in explants derived from intact or VE-stripped E5.5-E6.5 embryos $(n=15-20)$ cultured on FN. The Wilcoxon rank test was used for statistical analysis $\left[\left(^{* \star}\right) P \leq 0.01\right.$; $\left(^{* \star *}\right)$ $P \leq 0.001]$, and medians are depicted by a red stripe. $(F-I)$ Explants derived from VE-stripped E5.5 and E6.5 embryos cultured on FN and STO cells after AP staining. Arrowheads indicate PGCs. Bar, $150 \mu \mathrm{m}$.

ture $(P>0.4)$. Explants derived from whole E5.5-E6.0 embryos (containing intact extraembryonic tissues) cultured on FN developed similar numbers of PGCs to explants cultured on STO cells (Fig. 2E). Strikingly, VEstripped embryos isolated at E5.5-E6.0 did not develop PGCs when cultured on FN-coated coverslips instead of feeder cells, despite similar overall development of the 
explants (Fig. 2H,I). Some E5.5-VE-derived explants (three out of six explants) cultured on FN expressed Oct4 mRNA (Fig. 3A). Because these explants had no recognizable PGCs and Oct4 expression is not restricted to PGCs, the presence of PGC7/Stella mRNA was also analyzed. The lack of PGCs was confirmed by the absence of PGC7/Stella mRNA in all E5.5-VE-derived explants cultured on FN (Fig. 3A), whereas expression was observed

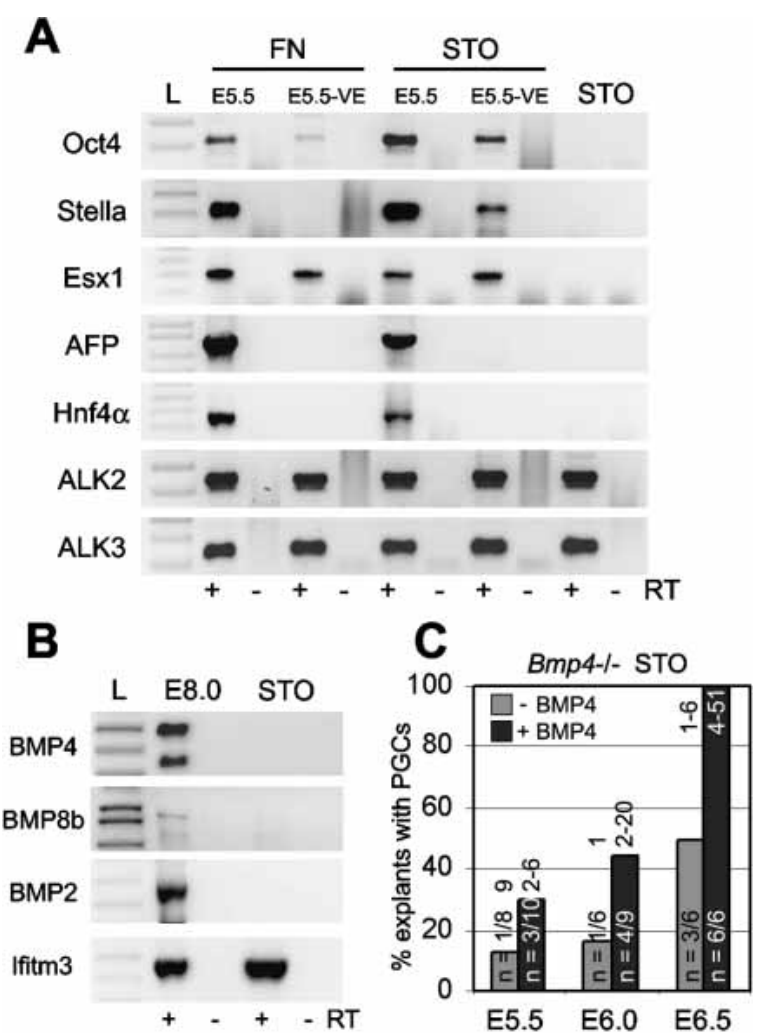

Figure 3. STO cells support the formation of PGCs in $\mathrm{Bmp4} 4^{-/-}$ mouse embryos. (A) Genes expressed in E5.5 explants cultured whole or without VE (-VE) either on STO cells or FN were studied by RT-PCR independently in three to six explants per group. Oct 4 mRNA was present in explants where PGCs were observed, but it was also detected in half of the E5.5-VE-derived explants analyzed cultured on FN (three out of six). PCG7/Stella mRNA was not detected in explants derived from E5.5-VE explants cultured on FN. Esx 1 mRNA was detected in samples $(40 \%-100 \%)$ of all explants groups analyzed. $\alpha$-Fetoprotein (AFP) and hepatocyte nuclear factor $4 \alpha(\mathrm{Hnf} 4 \alpha)$ mRNA was only present in explants derived from intact embryos (containing VE). ALK2 and ALK3 mRNA was detected in all samples analyzed, including STO cells. (B) Expression of BMP4, BMP8b, BMP2, and Ifitm3/Fragilis/mil-1 mRNA in STO cells determined by RT-PCR. cDNA from an E8.0 embryo was used as positive control. Contamination by genomic DNA did not occur as indicated by amplification of each sample without reverse transcription (-RT). (L) DNA ladder. $(C)$ The fraction $(n)$ represents the number of PGC-containing explants derived from E5.5, E6.0, and E6.5 $\mathrm{Bmp}^{4^{-1}}$ mouse half embryos (cut longitudinally) over the total number examined, cultured on STO cells in the presence (black bars) or absence (gray bars) of exogenous BMP4. The number of PGCs is presented as a range for each type of explant. in all other groups of E5.5-derived explants analyzed. Furthermore, we detected expression of Esx1 mRNA, a marker for ExE-derived tissues (Li et al. 1997) in E5.5derived explants independently of the presence of the VE (Fig. 3A). This indicated that the absence of PGCs observed in VE-stripped E5.5-derived explants cultured on FN was not the result of the possible degeneration of the ExE, but was specifically caused by the absence of the VE.

These results strongly indicate that in the absence of feeder cells, the VE in addition to the ExE is required for the formation of PGCs at E5.5-E6.0. However, culturing VE-stripped embryos on a fibroblast feeder layer instead of FN restored the potential of the epiblast cells to generate PGCs. The feeder cells (together with the ExE) could have allowed formation of PGCs by providing either direct signals to the epiblast or ExE or indirectly by promoting the de novo formation of endoderm.

\section{Influence of the STO feeder cell layer on explant culture}

To establish whether the PGC-inducing capacity of feeder cells was indirect and the result of de novo endoderm differentiation, we performed RT-PCR to detect expression of $\alpha$-fetoprotein (AFP) and hepatocyte nuclear factor $4 \alpha(\mathrm{Hnf} 4 \alpha)$ mRNA, both endoderm markers (Dziadek and Adamson 1978; Duncan et al. 1994; Gualdi et al. 1996; Kuo et al. 1997; Watt et al. 2001). We detected both AFP and $\mathrm{Hnf} 4 \alpha$ transcripts in explants derived from intact E5.5 embryos cultured on either FN or STO cells as expected, but not in E5.5-VE-derived explants (Fig. 3A). These results indicate that STO cells did not induce or support the formation of endoderm from VE-stripped embryos.

Interestingly, STO cells expressed mRNA for ALK2 and ALK3, the two type I BMP receptors detected in the VE (Fig. 3A), although no BMP4, BMP2, or BMP8b transcripts were detected (Fig. 3B). STO cells showed no or weak PS1/5/8 staining, but when treated with $100 \mathrm{ng} /$ $\mathrm{mL}$ of BMP4, nuclear PS1/5/8 staining was evident /data not shown), indicating that the BMP signaling pathway could be activated in the presence of sufficient ligand. Therefore, STO cells could be supporting formation of PGCs by translating BMP signals generated in the ExE (BMP4 or BMP8b). To test this hypothesis, we isolated E5.5-E6.5 embryos obtained from matings of $B \mathrm{mp} 4$ heterozygous mice, cut them longitudinally in two halves, and cultured them on STO cells in the presence or absence of exogenous BMP4. From all explants derived from E5.5-E6.5 Bmp4 heterozygous and wild-type littermates, $40 \%-87 \%$ contained PGCs, independently of the presence of exogenous BMP4 (data not shown). Furthermore, the number of PGCs was not significantly different between BMP4-treated and untreated explant groups, suggesting that addition of exogenous BMP4 is not sufficient to increase the number of PGCs formed, even at E5.5.

Surprisingly, several Bmp4-deficient explants were able to generate PGCs when cultured on STO cells, even 
in the absence of exogenous BMP4 (Fig. 3C). This clearly indicated that STO cells provided more than just an appropriate substratum or transduction of BMP4 from the ExE. STO cells thus have the ability to trigger $\geq$ E5.5 $\mathrm{Bmp4}^{-/-}$epiblast cells to adopt a PGC fate, together with possible signals from the $B m p 4^{-/-}$ExE or VE cells, that is, BMP8b and BMP2, respectively. It is of note that we also detected Ifitm3 transcripts in STO cells by RT-PCR (Fig. 3B).

\section{ALK2 is necessary for PGC formation in vivo}

The role of the VE in the formation of PGCs under feeder-free conditions was unexpected, as well as the observation that active BMP signaling was present at E5.5E6.0 in the VE, particularly at the junction between extraembryonic and embryonic ectoderm. This led us to investigate whether ALK2, one of the type I BMP receptors detected in the VE at these developmental stages, could be involved in formation of PGCs.

We examined the numbers of PGCs in embryos lacking Alk2 after AP staining and failed to identify any PGCs in these mutants at E7.5-E8.0, although their wild-type littermates (3-7 somites) contained a median number of 38 PGCs (Fig. 4). More interestingly, the Alk2 heterozygous embryos contained a reduced number of PGCs (median of 26) compared with wild-type litter-

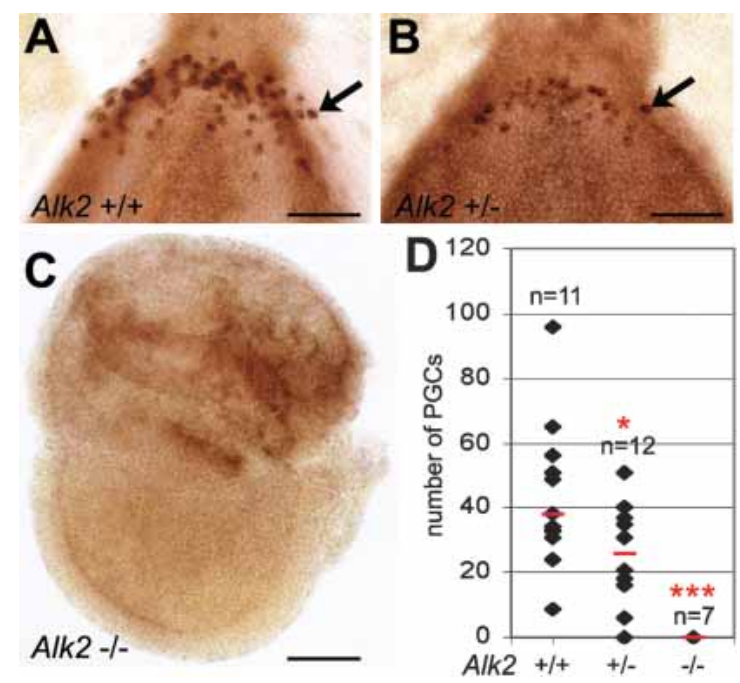

Figure 4. ALK2 is necessary for PGC formation. E7.5-E8.0 embryos resulting from crossings of Alk2 heterozygous mice were isolated and genotyped, and after AP staining, the number of PGCs present in the base of the allantois was analyzed. Alk2 heterozygous embryos contained a reduced number of PGCs (black arrow), when compared with wild-type littermates $(A, B)$, and Alk2 homozygous embryos contained no PGCs $(C)$. Note that as the result of squashing the embryos to allow an accurate counting of PGCs, the Alk2 mutant depicted in $C$ was inevitably ruptured, but the extent of somatic development was as described (Gu et al. 1999). (D) Number of PGCs detected in embryos of the three Alk2 genotypes. The Wilcoxon rank test was used for statistical analysis $\left[\left({ }^{\star \star \star}\right) P \leq 0.001\right.$; $\left.\left(^{\star}\right) P=0.06\right]$, and medians are depicted by a red stripe. Bar, $100 \mu \mathrm{m}$. mates $(P=0.06)$, resembling Bmp4 heterozygous embryos in this respect (Lawson et al. 1999). These results indicate that ALK2 is necessary for the formation of PGCs.

\section{Expression of constitutively active ALK2 in the VE} of $\mathrm{Bmp}^{-/-}$embryos induces formation of PGCs

Although formation of PGCs in vivo required ALK2 and E5.5-E6.0-derived explants required VE for the formation of PGCs in vitro, it was still unclear whether it is ALK2 activation of the BMP signaling pathway in the VE that causes proximal epiblast cells to adopt a PGC fate. To test this, we infected E5.5-E6.0 and E6.5 embryos generated from crossings of $\mathrm{Bmp} 4$ heterozygous mice with adenovirus expressing constitutively active (ca) Alk2 (which triggers BMP signaling in the absence of ligand) and cultured the embryos on FN. First, however, we infected intact E5.5 and E6.5 embryos with adenovirus expressing $L a c Z$ and showed that punctuated $\beta$-galactosidase staining (X-gal) was detected exclusively in the VE (Fig. 5A). Furthermore, we confirmed by Western blot analysis that infection of HepG2 cells with adenovirus encoding caAlk2 (caAlk2-virus) induced phosphorylation of BMP receptor-regulated Smads (PS1/5/8) as did exposure to exogenous BMP4 (Fig. 5B). Intact E5.5 $B R E: L a c Z$ transgenic embryos infected with caAlk2-virus showed several X-gal-positive VE cells after $1 \mathrm{~d}$ of culture, whereas E5.5 BRE:LacZ transgenic embryos showed no detectable X-gal staining (data not shown). Using E6.5 BRE:LacZ transgenic embryos, we observed activation of BMP signaling, in particular, in the mesoderm (and no longer in the VE), but infection with caAlk2-virus resulted in ectopic activation of BMP signaling in a punctuated fashion in the VE as expected, in addition to BMP signaling in some epiblast cells and in the mesoderm, which developed better than in controls probably as result of activation of BMP signaling (Fig. 5C; data not shown). Together, these data indicate that adenoviral infection is effective in E5.5-E6.5 intact embryos, occurred in the VE, and that expression of caALK2 resulted in activation of BMP signaling in embryos in vitro and enhanced development of mesodermal tissue.

After infection with caAlk2-virus, PGCs were identified in explants derived from E5.5-E6.0 Bmp4 homozygous knockout embryos at similar frequencies as in heterozygous and wild-type littermates (Fig. 5D). This indicated that activation of the BMP signaling pathway via caALK2 in the VE of Bmp4-deficient embryos is sufficient to induce the formation of PGCs around E6.0-E6.5 (when the product encoded by the adenovirus becomes expressed). In addition, only one out of four caAlk2-infected explants derived from E6.5 Bmp4 homozygous embryos formed PGCs (Fig. 5D), probably because when caALK2 is expressed (E7.0), the window of PGCs specification is closed.

To investigate whether activation of the BMP signaling pathway via caALK2 directly in the epiblast (or ExE) could lead to the formation of PGCs, we also infected wild-type E5.5-E6.0 and E6.5 embryos with and without 
A

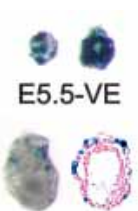

E5.5

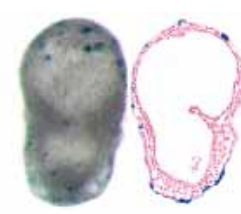

E6.5

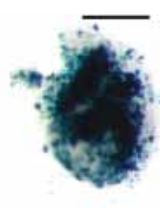

E6.5-VE
B
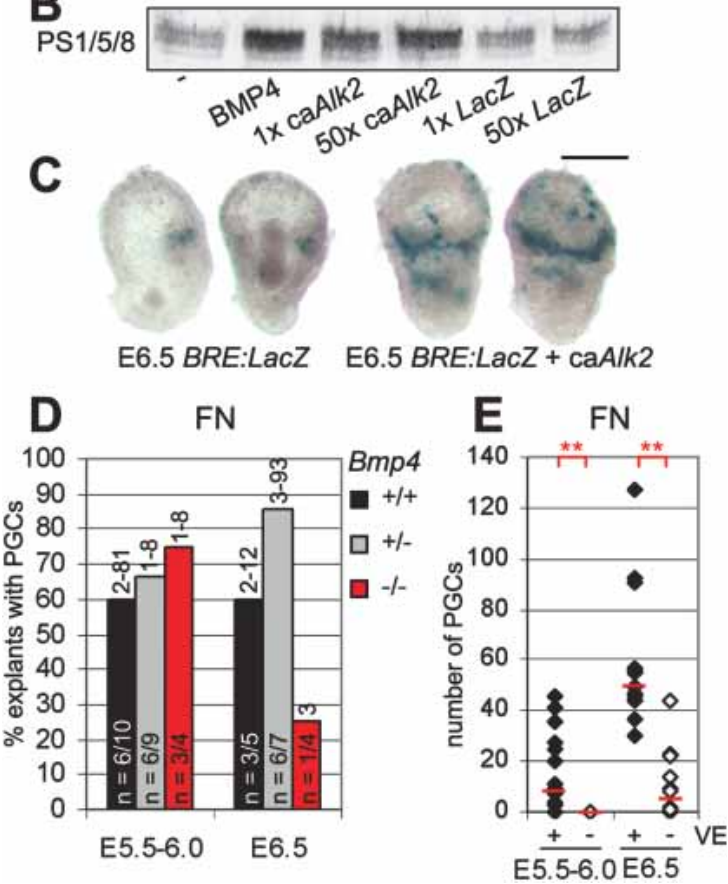

Figure 5. Expression of caALK2 in $\mathrm{Bmp}^{-/-}$embryos rescues the PGC defects. (A) The efficiency of adenoviral infection was studied in intact or VE-stripped E5.5 and E6.5 embryos cultured overnight on FN using adenovirus containing a LacZ expression construct (LacZ-virus). X-gal staining was detected in intact embryos exclusively in the $\mathrm{VE}$ and in the majority of the cells of VE-stripped derived explants. Bar, $300 \mu \mathrm{m}$. (B) Western blot analysis of the C-phosphorylated form of BMP-responsive Smads (PS1/5/8) in HepG2 cells (-); HepG2 cells treated for $1 \mathrm{~h}$ with exogenous BMP4; infected with two concentrations of adenovirus containing a caAlk2 expression construct (caAlk2-virus); and two different concentrations of LacZ-virus. (C) Analysis of X-gal staining of BRE:IacZ heterozygous E6.5 embryos cultured overnight on FN in the presence or absence of caAlk2virus. $(D)$ The fraction $(n)$ represents the number of PGC-containing explants derived from intact E5.5-E6.0 and E6.5 embryos (from crossings of $\mathrm{Bmp} 4$ heterozygous mice) infected with caAlk2-virus over the total number examined cultured on FN. The number of PGCs is presented as a range for each type of explant. (E) Number of PGCs detected in explants derived from intact or VE-stripped E5.5-E6.0 and E6.5 embryos $(n=12-18)$ infected with caAlk2-virus and cultured on FN. The Wilcoxon rank test was used for statistical analysis $\left[\left(^{\star \star}\right) P \leq 0.01\right]$, and medians are depicted by a red stripe.

VE with caAlk2-virus and cultured the embryos in vitro on FN. The results (Fig. 5E) were similar to those obtained in the absence of infection by caAlk2-virus (Fig. $2 \mathrm{E})$, even though VE-stripped embryos could be effectively infected (Fig. 5A), clearly indicating that overex- pression of caALK2 in E5.5-E6.0 epiblast (or ExE) in the absence of VE is not sufficient to induce formation of PGCs. Therefore, these results support the conclusion that the rescue of $\mathrm{Bmp4}^{-/-}$embryos by caALK2 was via $\mathrm{BMP}$ signaling in the VE, not in the epiblast.

$V E$ surrounding both the ExE and proximal epiblast is important for the formation of PGCs

Finally, we investigated the role of ExE in the generation of PGCs. We removed the ExE and most proximal epiblast cells (with the surrounding VE), cultured the rest of the embryo on FN, and after $3 \mathrm{~d}$ determined the number of PGCs. Explants derived from E6.0 embryos formed no PGCs, independently of the presence of exogenous BMP4 (Table 1), caAlk2-virus, or both $(n=17$ and 19 , respectively; data not shown). These data suggested that at E6.0, either BMP4 signaling cannot replace ExE and additional factors, like BMP8b, are needed to induce PGC formation or, alternatively, that the VE cells surrounding the ExE and most proximal epiblast cells (where BMP signaling is observed in vivo) are necessary for induction of PGCs. We addressed this question by culturing recombinate E6.0-derived explants consisting of "cup-shaped" VE (containing both the cell population that surrounds the ExE and the epiblast) filled with two distal epiblast fragments (Table 1). In these recombinates, the presence of the total VE supported the development of some PGCs in a few explants, but the incidence was too low to display a significant effect of either addition of exogenous BMP4 or ExE. Of note is that recombinate explants formed PGCs in culture less efficiently than whole E6.0 embryos $(P<0.01)$. Recombinate explants derived from E6.5 embryos developed better in culture. In this case,

Table 1. Role of the ExE and the VE surrounding both the ExE and proximal epiblast in the formulation of PGCs

\begin{tabular}{|c|c|c|c|c|c|}
\hline Stage & $\begin{array}{l}\text { Type of } \\
\text { explant }\end{array}$ & BMP4 & $\begin{array}{c}\% \\
\text { Survival }^{\mathrm{a}}\end{array}$ & $\begin{array}{l}\% \text { with } \\
\text { PGCs }{ }^{b}\end{array}$ & Range $^{c}$ \\
\hline \multirow[t]{6}{*}{ E6.0 } & Whole $^{\mathrm{d}}$ & - & $100(n=18)$ & $61(n=18)$ & $2-88$ \\
\hline & Emb. part ${ }^{\mathrm{e}}$ & - & $44(n=16)$ & $0(n=7)$ & - \\
\hline & Emb. part & + & $100(n=21)$ & $0(n=7)$ & - \\
\hline & $\underset{\mathrm{Ex}+\mathrm{d}+}{\mathrm{ExE}^{\mathrm{f}}}$ & - & $71(n=17)$ & $17(n=12)$ & $1-5$ \\
\hline & $\mathrm{VE}+\mathrm{d}^{\mathrm{g}}$ & - & $83(n=18)$ & $7(n=15)$ & 3 \\
\hline & $\mathrm{VE}+\mathrm{d}$ & + & $80(n=15)$ & $25(n=12)$ & $2-4$ \\
\hline \multirow[t]{6}{*}{ E6.5 } & Whole & - & $100(n=14)$ & $100(n=14)$ & $2-76$ \\
\hline & Emb. pa & - & $100(n=16)$ & $31(n=16)$ & $2-7$ \\
\hline & Emb. part & + & $100(n=15)$ & $27(n=15)$ & $1-54$ \\
\hline & $\begin{array}{c}\mathrm{VE}+\mathrm{d}+ \\
\mathrm{ExE}\end{array}$ & - & $93(n=15)$ & $64(n=14)$ & $1-36$ \\
\hline & $\mathrm{VE}+\mathrm{d}$ & - & $88(n=16)$ & $14(n=14)$ & $1-2$ \\
\hline & $\mathrm{VE}+\mathrm{d}$ & + & $100(n=17)$ & $53(n=17)$ & $2-24$ \\
\hline
\end{tabular}

${ }^{a}$ Percentage viable explants in culture (from $\left.n\right) ;{ }^{b}$ percentage explants that developed PGCs in culture (from n); ${ }^{c}$ range of number of PGCs; ${ }^{\mathrm{d}}$ whole embryo; ${ }^{\mathrm{e} e m b r y o n i c}$ part of the embryo (epiblast and VE) with the most proximal cells removed; ${ }^{f}$ recombinate of "cup shaped" VE filled with a fragment of distal $1 / 3$ epiblast (d) and of ExE; "recombinate of "cup shaped" VE filled with two fragments of distal epiblast. 
exposure of the whole VE containing two distal epiblast fragments to exogenous BMP4 or filling the VE-cup with one distal epiblast fragment and one ExE fragment resulted in a higher number of explants containing PGCs (Table 1) and a significant increase in the number of PGCs $(P<0.05$ and $P<0.01$ for the two treatments, respectively). Unexpectedly, 30\% of the E6.5-derived embryonic explants (lacking the most proximal cells) exhibited PGCs (Table 1); these explants may have still contained VE tissue able to induce the formation of PGCs.

\section{Discussion}

ExE and VE are both essential for PGC allocation at E5.5-E6.0

Of the three BMP ligands known to be involved in the development of PGCs, BMP4 and BMP8b are produced in the ExE at E5.5-E7.5 (Lawson et al. 1999; Ying et al. 2000), whereas BMP2 is expressed slightly earlier at E5.0-E7.5 in the VE (Coucouvanis and Martin 1999). Thus, a role for the VE as well as the ExE in PGC formation has been suggested but never fully elucidated. One reason for this is that most studies on the generation of PGCs in vitro have been performed by culturing embryos on a layer of feeder cells.

We observed the appearance of PGCs in E5.5-6.0 VEstripped embryos (epiblast and ExE) cultured on STO cells, but not in parallel cultures on $\mathrm{FN}$, indicating that in the absence of feeder cells, E5.5-E6.0 epiblast cells are not able to develop PGCs independently of signals provided by both extraembryonic tissues, VE and ExE. This suggests that although BMP signals generated in the ExE at E5.5-E6.0 are necessary to induce PGCs in the epiblast, in vitro they are clearly not sufficient and the presence of the VE is also required. Additionally, we demonstrated that the presence of the VE surrounding the ExE and the proximal epiblast in particular is important for inducing naive (distal) epiblast cells from E6.5 embryos to form PGCs, if provided with a source of BMP4 (exogenous BMP4 or ExE), although comparable experiments with E6.0 embryos were inconclusive.

At E6.5, complete epiblast was capable of generating PGCs independently of VE or ExE, although the numbers of PGCs observed were significantly reduced compared with explants derived from intact embryos, suggesting that signals from the VE are still important at that stage, but no longer strictly necessary. In agreement with these data, Yoshimizu et al. (2001) observed that when cultured on FN, isolated E6.0 epiblasts were unable to develop PGCs, whereas $40 \%$ of the explants derived from E6.25 epiblasts contained PGCs. Together, these results demonstrate that under feeder-free culture conditions, isolated epiblast cells from $\leq$ E6.0 embryos are not able to form PGCs autonomously, but require external signals provided not only by the ExE, but also by the VE.

\section{ALK2 functions as a type I receptor for BMP4}

Activated BMP Smad-dependent signaling was detected at E5.5-E6.0 in the proximal epiblast and in the VE.
Smad1, Smad5, and Smad8 are generally activated by BMPs, but they can also be activated by TGF $\beta$ (via type I receptor ALK1; Oh et al. 2000), but not by nodal (Kumar et al. 2001). However, ALK1 mRNA is only expressed from E6.5 onward (Roelen et al. 1997b), in contrast to ALK2, ALK3, and ALK6 mRNA, which were expressed earlier in the embryo. Both ALK3 and ALK6 are wellcharacterized type I receptors that translate signals from BMPs of both the DPP class (BMP2 and BMP4) and 60A class (BMP5, BMP6, BMP7, BMP8a, and BMP8b). ALK2, on the other hand, is known to translate signals from BMPs of the $60 \mathrm{~A}$ class, but the relationship with the DPP class is less clear. Although BMP2 has been shown to bind ALK2 and activate the BMP signaling pathway (Liu et al. 1995), it has not been formally shown that BMP4 also has this capacity.

In this study, we have provided the first evidence that ALK2 functions in vivo as a type I receptor for BMP4. First, we demonstrated that $A 1 k 2^{-/-}$embryos form no PGCs, whereas in $A l k 2^{+/-}$embryos, the number of PGCs was reduced when compared with wild-type littermates. This reflected the findings in mutant $B m p 4$ mice, where $B \mathrm{mp} 4^{+/-}$embryos had reduced numbers of PGCs and $\mathrm{Bmp}^{-/-}$lacked PGCs entirely (Lawson et al. 1999). Second, we were able to rescue the formation of PGCs in $\mathrm{Bmp}^{-/-}$embryos by expressing caALK2 in the VE, which mimicked activation of the BMP pathway, but we were not able to rescue formation of PGCs by expressing caALK2 in VE-stripped wild-type embryos. Furthermore, note that the percentage of explants from $\mathrm{Bmp4}^{-/-} \mathrm{mu}-$ tants containing PGCs is increased in the presence of caALK2 (Figs. 3C, 5D), becoming similar to wild-type littermates and supporting the idea that ALK2 is indeed able to mediate BMP4 activity. In contrast, because of the relatively low levels of infection, the numbers of PGCs observed were not significantly different from noninfected controls. These data indicate a role for ALK2 specifically in the VE, transducing BMP signals necessary for formation of PGCs (and extraembryonic mesoderm).

Although it is not known whether the downstream intracellular targets of ALK2 are distinct from those of ALK3 and ALK6, it is clear that ALK2 is crucial for the formation of PGCs and that in its absence, neither ALK3, the other BMP type I receptor detected in the VE at E5.5E6.0, nor ALK6 is capable of supporting formation of PGCs. We do not know which type II BMP receptor partners ALK2 in the visceral endoderm, although all type II BMP receptors are functional before gastrulation (Song et al. 1999; Beppu et al. 2000). In addition, Smad5 mRNA was not detected in the VE at E6.5 (Chang et al. 1999), whereas Smad1 is clearly expressed in the VE before gastrulation. More importantly, deficiency in Smad1 results in complete absence of PGCs (Hayashi et al. 2002), resembling deficiency in either Alk2 or Bmp4.

\section{Indirect BMP signaling controls PGC formation} at E5.5-E6.5

Based on the data reported here, we propose that a still unknown signal, regulated by BMP4 (and probably 
BMP2, possibly BMP8b) activation of ALK2 in the VE surrounding ExE and proximal epiblast is involved in directing proximal epiblast cells toward a PGC (and possibly allantoic) fate, at E5.5-E6.0 (Fig. 6). This would explain why embryos without VE but containing the ExE (and therefore able to produce BMP4 and BMP8b) were unable to form PGCs when cultured under feeder-free conditions.

$B m p 2^{-/-}$mutants form a reduced number of PGCs (Ying and Zhao 2001). More importantly Bmp2 $2^{+-}$; $B \mathrm{mp} 4^{+/-}$double heterozygotes had fewer PGCs compared with single $B m p 4$ or $B m p 2$ heterozygous embryos (Ying and Zhao 2001), suggesting that BMP4 and BMP2 have additive effects in the induction of PGCs. This was expected because BMP4 and BMP2, although produced in different tissues, have similar structures and share the same signaling pathway. Interestingly, additive effects were not observed between either BMP2 or BMP4 with BMP8b (Ying et al. 2000; Ying and Zhao 2001). On a mixed genetic background, in contrast to the absence of PGCs in Bmp4-, Alk2-, and Smad1-deficient embryos, at least $50 \%$ of $B M P 8 b$ - or Smad5-deficient embryos contained PGCs, although in reduced numbers (Lawson et al. 1999; Ying et al. 2000; Chang and Matzuk 2001; Hayashi et al. 2002), and BMP8b may therefore signal independently of BMP4/2 via Smad5 (and Smad1; Fig. 6).

PGCs are completely absent in Bmp4 homozygous embryos. The observation that activation of BMP signaling in the VE (by caALK2) was sufficient to induce PGCs in $\mathrm{Bmp4}^{-/-}$embryos at E6.0-E6.5 supported our hypothesis that the BMP-ALK2-mediated signal produced by the VE is important for generation of PGCs in the embryo. Moreover, it implies that at least part of the BMP signal from the ExE indirectly induces the development of PGCs from epiblast cells via the VE surrounding the ExE and proximal epiblast (Fig. 6).

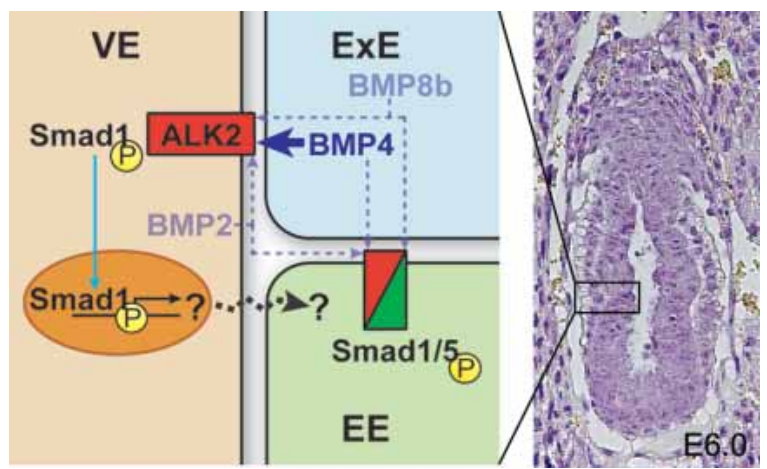

Figure 6. BMP signaling and the formation of PGCs. At E5.5E6.0, BMP4 secreted by the ExE binds to BMP receptor complexes consisting of BMP receptor type II and ALK2 in the VE, which results in Smad1 phosphorylation and transcriptional regulation of BMP target genes. Among these target genes, an unknown factor (or factors) directs proximal epiblast cells toward a PGC (and possibly allantoic) fate. BMP2 produced by the VE and BMP8b produced by the ExE possibly signal together with BMP4 in the VE. However, we cannot exclude that all three BMPs act directly on the proximal epiblast via ALK2 (red) or possibly ALK3 (green) and Smad1/5.

\section{The role of feeder cells in PGC development in vitro}

The outcomes of experiments using different feeder cells to study the development of PGCs demonstrate that the assays are not equivalent. Yoshimizu et al. (2001) cultured E6.25 proximal epiblasts on STO and on SI/SI cells and obtained different results both with respect to the percentage of explants with PGCs $162 \%$ vs. 35\%, respectively) and the number of PGCs (ranging from 1 to 45 vs. 4 to 7 , respectively). This suggests that STO cells in particular provided important external support for the development of PGCs in culture.

Ying et al. (2001) were unable to detect PGCs by culturing E6.0-E6.25 $\mathrm{Bmp}^{-1-}$ embryos on transgenic BMP4-producing COS7 cells. We were therefore surprised that $B m p 4^{-/}$embryos cultured on STO cells formed PGCs. The formation of PGCs supported by STO cells was not mediated by inducing endoderm formation, nor by transducing BMP4 signals produced by the ExE. A possible explanation could be that STO cells respond to BMP8b produced by the ExE. However, it is more likely that STO cells produce either a similar signal to the postulated BMP-ALK2-mediated signal generated in the VE, or a downstream signal similar to that produced by proximal epiblast cells themselves. Presumably, COS7 cells produce this signal less efficiently. Of note, a recent report has shown that in contrast to STO/SNL cells, some STO cell lines (from ATCC) may express BMP4 (Qi et al. 2004).

STO cells express leukemia inhibitory factor, steel factor, and mast-cell growth factor, among other diffusible factors known to stimulate PGC proliferation and survival in culture (Dolci et al. 1991; Godin et al. 1991). Furthermore, we detected Ifitm 3 mRNA by RT-PCR in STO cells. Together, these factors could provide an environment that is permissive not only for proliferation and survival, but also for the induction of PGCs in culture. Ifitm 3 expression in the epiblast is reduced in a dose-related manner in the Bmp4 mutant embryos and colocalizes with PGCs as they form (Saitou et al. 2002; Tanaka and Matsui 2002).

Interestingly, STO cells are able to support the development of PGCs in VE-stripped E5.5-E6.0 embryos, isolated E6.0 whole or proximal epiblasts (Yoshimizu et al. 2001), but not distal E6.0 epiblasts (Yoshimizu et al. 2001). Thus, the signals produced by STO cells are not sufficient to induce ectopic PGCs.

The epiblast needs BMP4 at E5.5-E6.0 to develop (PGCs) in culture

Although E6.5 $\mathrm{Bmp}^{-/-}$embryos developed well in close contact with STO cells and formed PGCs, E5.5-E6.0 $\mathrm{Bmp}^{-{ }^{--}}$embryos developed poorly and only few formed PGCs. However, more explants contained PGCs when BMP4 was added to the culture medium. We suggest that the signals produced by STO cells are not sufficient to induce PGCs effectively in cultured embryos prior to E6.0, but additional BMP signals may be necessary to support general development and subsequently PGCs 
may form. PGCs were formed in VE-stripped E5.5 embryos cultured on STO cells probably because in addition to the STO-produced signals, BMPs are being produced in the ExE. In the absence of ExE and VE, E5.5-E5.75 epiblasts cultured on STO cells only formed PGCs when BMP4 was added to the culture medium (Hayashi et al. 2002). Moreover, Hayashi et al. (2002) observed that E5.5-E5.75 Smad1 ${ }^{-/-}$mutant epiblasts on STO cells did not develop PGCs, even in the presence of exogenous BMP4. In agreement with the results above, Toyooka et al. (2003) recently showed that germ cells were formed in coaggregates of embryonic stem (ES) cells with transgenic BMP4-producing feeders, including STO cells, immediately after $1 \mathrm{~d}$ of culture, but germ cells were not observed within $1 \mathrm{~d}$ in aggregates of ES cells only cultured in the presence of exogenous BMP4 or in coaggregates of ES cells with STO cells.

Taken together, the results indicated that at E5.5E6.0, BMP signals-that is, BMP4-are necessary not only specifically for the generation of PGCs but probably for the general development and differentiation of E5.5E6.0 epiblast cells in culture, as also suggested by Pesce et al. (2002).

\section{Material and methods}

\section{Isolation of embryos and culture of embryonic explants}

The genetic background of the ActRIA ${ }^{\mathrm{tm} 1 \mathrm{Enl}}$ (also known as Acvr $1^{\text {tmlEnl }}$ ) mice (Gu et al. 1999) was BL6/129 and of both wild-type and $B m p 4^{\text {tm1Blh }}$ mice (Lawson et al. 1999) was BL6/ CBA. Oct4 $\triangle P E: g f p$ transgenic mice were generated as described by Anderson et al. (1999) on a BL6/CBA background. BRE:LacZ transgenic mice were generated using the BRE promoter sequence (Korschynskyi and ten Dijke 2002) coupled to LacZ on a $25 \%$ BL6/75\% 129 and will be published separately (Monteiro et al. 2004).

The mice were kept in a normal or reversed light/dark cycle, and the noon of day (12:00) of the vaginal plug was designated E0.5 or E0.0, respectively. Uteri isolated from mice killed by cervical dislocation were kept in cold Dulbecco's minimal essential medium (DMEM; Invitrogen) supplemented with 7.5\% fetal calf serum (FCS) and $10 \mathrm{mM}$ HEPES. E5.5, E6.0, and E6.5 embryos were isolated using tungsten needles to remove both the Reichert's membrane and the ectoplacental cone, and staged according to Yoshimizu et al. (2001).

For the culture of embryonic explants, we used (1) whole embryos, consisting of intact epiblast, ExE, VE, and, at E6.5, primitive streak and nascent mesoderm; (2) whole embryos cut longitudinally (through the axis of bilateral symmetry, if this was morphologically discernible) using glass needles, but containing parts of all tissues described above; (3) embryos containing both an intact epiblast and ExE plus, depending on the stage, the primitive streak, and nascent mesoderm, but with the VE layer removed as described (Roelen et al. 1994); (4) embryos with the ExE, proximal epiblast cells, and surrounding VE removed; (5-6) recombinants formed by intact "cup-shaped" isolated VE filled with either two fragments of most distal epiblast or one fragment of distal 1/3 epiblast and one fragment of ExE. Each individual embryo/explant was cultured on a glass coverslip either covered with a confluent layer of mitomycin C-treated STO/ SNL feeder cells $\left(7.5 \times 10^{4}\right.$ cells/well) or coated with FN (20 $\mathrm{ug} / \mathrm{mL}$; Harbor BioProducts) in 4-well culture plates (NUNC). Explants derived from E5.5 embryos were cultured for $4 \mathrm{~d}$ and E6.0 and E6.5 embryos for $3 \mathrm{~d}$. When used, BMP4 (R\&D systems) was added to the culture medium at $100 \mathrm{ng} / \mathrm{mL}$.

\section{Analysis of primordial germ cells}

PGCs were identified and counted on the basis of AP activity and morphology using a $20 \times$ objective (Axioplan; Zeiss) as described by Lawson et al. (1999). The Wilkoxon nonparametric rank test was used to compare the presence and number of PGCs between the different groups of embryos/explants.

\section{Immunohistochemistry}

BMP receptor-regulated Smads were detected in wild-type E5.5E6.5 embryos using rabbit anti-PSmad1/5/8 antibody (Persson et al. 1998) by whole-mount immunohistochemistry as described (Chuva de Sousa Lopes et al. 2003).

After the removal of the VE layer, heterozygous Oct4DPE:gfp E6.0 embryos were cultured for $3 \mathrm{~d}$ on STO cells (as described above) and used for detection of PGC7/Stella and Oct4. After fixation in $4 \%$ paraformaldehyde/PBS (PFA) for $2 \mathrm{~h}$ at $4^{\circ} \mathrm{C}$, the explants were washed three times in PBS, permeabilized $8 \mathrm{~min}$ with $0.1 \%$ Triton X-100 (Merck), washed three times in PBS, blocked with $4 \%$ normal goat serum (Dako) with $0.05 \%$ Tween (Merck) for $1 \mathrm{~h}$ at room temperature, incubated $1 \mathrm{~h}$ at room temperature with rabbit anti-PGC7/Stella antibody (Sato et al. 2002) diluted 1:2000 in blocking solution, washed three times in $0.05 \%$ Tween, and incubated $1 \mathrm{~h}$ at room temperature with Cy3-conjugated goat anti-rabbit antibody (Jackson Immuno Research Laboratories, Inc.) diluted 1:250 in blocking solution. After staining, the explants were immediately analyzed for GFP-positive cells (Oct4) and Cy3-positive cells (PGC7/Stella) using epifluorescent microscopy (Axioplan; Zeiss). Thereafter, the explants were washed three times in PBS, kept for $1 \mathrm{~h}$ in $70 \%$ ethanol at $4^{\circ} \mathrm{C}$, washed three times in distilled water, and treated with AP-staining solution, as above.

\section{Genotyping of embryos and embryonic explants}

Samples were boiled in $10 \mu \mathrm{L}$ of $0.1 \% \mathrm{~W} 1$ (Sigma) for 5 min and, after the addition of $10 \mu \mathrm{L}$ of proteinase $\mathrm{K}(2 \mathrm{mg} / \mathrm{mL}$; Invitrogen), incubated overnight $(\mathrm{o} / \mathrm{n})$ at $55^{\circ} \mathrm{C}$, then boiled $5 \mathrm{~min}$, and the DNA was amplified by PCR. The $B m p 4$ mutation was detected with primers 5'-CCAGACTAGTCCATCACAATG-3' and $5^{\prime}$-TTGAGGTGATCAGCCAGTGGA-3', and amplification conditions $5 \mathrm{~min}$ at $94^{\circ} \mathrm{C}, 40$ cycles of $15 \mathrm{sec}$ at $94^{\circ} \mathrm{C}, 30 \mathrm{sec}$ at $60^{\circ} \mathrm{C}$, and $45 \mathrm{sec}$ at $72^{\circ} \mathrm{C}$, followed by $5 \mathrm{~min}$ at $72^{\circ} \mathrm{C}$. Thereafter, the amplified product was digested overnight with SfiI $(214+227$ bp wild-type and 441 bp knockout). Neomycin primers were $5^{\prime}$-GATTGCACGCAGGTTCTC-3' and 5'-GATGT TTCGCTTGGTGGTC- $3^{\prime}$, and amplification conditions were 5 min at $94^{\circ} \mathrm{C}, 35$ cycles of $30 \mathrm{sec}$ at $94^{\circ} \mathrm{C}, 30 \mathrm{sec}$ at $58^{\circ} \mathrm{C}$, and 30 sec at $72^{\circ} \mathrm{C}$, followed by $10 \mathrm{~min}$ at $72^{\circ} \mathrm{C}$ to distinguish Alk2 heterozygous from wild-type embryos.

\section{$R T-P C R$}

Individual embryos, individual explants, and STO cell culture were frozen in liquid nitrogen and stored at $-80^{\circ} \mathrm{C}$. mRNA was isolated using Dynabeads mRNA DIRECT Micro kit (Dynal). Half of each sample was used for RT-PCR by standard procedures, and the other half was used as control for DNA contamination. Amplification conditions were $2 \mathrm{~min}$ at $94^{\circ} \mathrm{C}, 2$ cycles of $15 \mathrm{sec}$ at $94^{\circ} \mathrm{C}, 30 \mathrm{sec}$ at $60^{\circ} \mathrm{C}$, and $5 \mathrm{~min}$ at $72^{\circ} \mathrm{C}$, followed by 
2 min at $94^{\circ} \mathrm{C}$ except for BMP8b cDNA (Toyooka et al. 2003) and ALK6, Oct4, Esx1, AFP, and Ifitm3 cDNA (annealing temperatures $55^{\circ} \mathrm{C}, 55^{\circ} \mathrm{C}, 55^{\circ} \mathrm{C}, 58^{\circ} \mathrm{C}$, and $62^{\circ} \mathrm{C}$, respectively). Heminested PCR of 30 cycles was used to detect PGC7/Stella, BMP4, BMP2, ALK3, ALK2, and ALK6 cDNA. The primers used for PGC7/Stella were $5^{\prime}$-TTGCAGCCGTACCTGTGGAGAA -3', 5'-GAGAAGGGTCCGCACTTTGTTG-3', 5'-GTGCAGA GACATCTGAATGGCTC-3'; for ALK2 the primers were 5'GGAGTAATGATCCTTCCTGTGC-3' , 5' -TCTTACACGTCA TCTTCCCCTG-3', and 5'-ACCACCGAGAGGATGATAAG GC-3'; for ALK6 they were 5'-ACGGAGCAGTGATGAGT GTCT-3', 5'-TTCTGGGTTCCTCTGTGTCTG-3', and 5'-TC TGAACTCACTGGGCAGTAG-3'; for GAPDH， 5'-AGCCA AAAGGGTCATCATCTCC-3' and 5'-CGAAGGTGGAAGA GTGGGAGTT-3'; for Ifitm3， 5'-ATCCTTTGCCCTTCAGT GCTGC-3' and 5'-TTCAGGACCGGAAGTCGGAATC-3'; and primers for BMP4, BMP2, ALK3, BMP8b, Hnf4 $\alpha$, Oct4, Esx1, and AFP have been described by Roelen et al. (1997a), Toyooka et al. (2003), Fujikura et al. (2002), Levenberg et al. (2002), Inoue et al. (2002), and Goumans et al. (1999).

\section{Adenoviral infection, cell culture, and Western blot analysis}

Intact or VE-stripped E5.5-E6.0 and E6.5 embryos were infected overnight with adenoviruses expressing constitutively active caAlk2 or LacZ (Fujii et al. 1999), refreshed and cultured on FN-coated coverslips at $37^{\circ} \mathrm{C}$ and $5 \% \mathrm{CO}_{2}$. A total of $0.5 \times 10^{7}$, $1 \times 10^{7}$, and $1.5 \times 10^{7}$ virus particles per $250 \mu \mathrm{L}$ were used for individual E5.5, E6.0, and E6.5 embryos, respectively. Embryonic explants and BRE:LacZ embryos were fixed for $2 \mathrm{~h}$ in $4 \%$ PFA at $4^{\circ} \mathrm{C}$, washed three times in PBS, and either stained for $\mathrm{X}$-gal using standard procedures after overnight culture or stained for AP activity as described above after 3 or $4 \mathrm{~d}$ in culture. Some embryo/explants were embedded in plastic and sectioned as described (Lawson et al. 1999).

The human hepatic cell line HepG2 (ATCC HB-8065) was maintained in DMEM supplemented with $10 \%$ FCS at $37^{\circ} \mathrm{C}$ and $7.5 \% \mathrm{CO}_{2}$. For adenovirus infection, 30,000 cells $/ \mathrm{cm}^{2}$ were seeded in 12-wells (Greiner bio-one) grown overnight and either infected with $1 \times 10^{7}$ and $50 \times 10^{7}$ virus particles in $2 \mathrm{~mL}$ of medium overnight or treated with $100 \mathrm{ng} / \mathrm{mL}$ BMP4 for $1 \mathrm{~h}$. Thereafter, protein isolation for Western blotting was performed using RIPA (Faure et al. 2000) and $35 \mu \mathrm{g}$ of total lysate separated by $12.5 \%$ SDS-PAGE and transferred to Hybond-C Extra nitrocellulose (Amersham Biosciences). The membrane was washed in TBST $(0.05 \mathrm{M}$ Tris- $\mathrm{HCl}$ at $\mathrm{pH} 7.5,0.14 \mathrm{M} \mathrm{NaCl}$, $0.1 \%$ Tween), blocked in $3 \%$ skimmed milk/TBST for $30 \mathrm{~min}$ at room temperature, washed in TBST, incubated with rabbit antiPSmadl antibody $(1: 1000)$ in TBST overnight at $4^{\circ} \mathrm{C}$, washed in TBST, incubated with HRP-conjugated goat anti-rabbit antibody (1:5000, BD Biosciences) in TBST for $1 \mathrm{~h}$ at room temperature, washed in TBST, and analyzed with the ECL kit (Amersham Biosciences) followed by exposure to X-ray film (Fuji).

\section{Acknowledgments}

We thank Z. Wang, M.J. Goumans, and A. Feijen for technical assistance and are grateful to H. Schöler for the Oct4 $\Delta P E: g f p$ construct used to generate transgenic mice, B. Hogan for the $B m p 4^{\mathrm{tm} l b l h}$ mice, T. Nakano for the rabbit anti-PGC7/Stella antibody, P. ten Dijke for the rabbit anti-PS1/5/8 antibody and the adenovirus used in this study, and B. Defize for comments on the manuscript. S.C.S.L. was supported by FCT (SFRH/BD/ 827/2000), R.M. by FCT (SFRH/BD/1144/2000) and NWO (ALW809-67-024), B.R. and H.L. by NIDDK (DK-19406 and DKD02716), and E.L. by NIH RO1 (HD35286).
The publication costs of this article were defrayed in part by payment of page charges. This article must therefore be hereby marked "advertisement" in accordance with 18 USC section 1734 solely to indicate this fact.

\section{References}

Anderson, R., Fässler, R., Georges-Labouesse, E., Hynes, R.O., Bader, B.L., Kreidberg, J.A., Schaible, K., Heasman, J., and Wylie, C. 1999. Mouse primordial germ cells lacking $\beta 1$ integrins enter the germline but fail to migrate normally to the gonads. Development 126: 1655-1664.

Beppu, H., Kawabata, M., Hamamoto, T., Chytil, A., Minowa, O., Noda, T., and Miyazono, K. 2000. BMP type II receptor is required for gastrulation and early development of mouse embryos. Dev. Biol. 221: 249-258.

Chang, H. and Matzuk, M.M. 2001. Smad5 is required for mouse primordial germ cell development. Mech. Dev. 104: 61-67.

Chang, H., Huylebroeck, D., Verschueren, K., Guo, Q., Matzuk, M.M., and Zwijsen, A. 1999. Smad5 knockout mice die at mid-gestation due to multiple embryonic and extraembryonic defects. Development 126: 1631-1642.

Chiquoine, A.D. 1954. The identification, origin and migration of primordial germ cells in the mouse embryo. Anat. Rec. 118: $135-146$.

Chuva de Sousa Lopes, S.M., Carvalho, R.L., van den Driesche S., Goumans, M.J., ten Dijke, P., and Mummery, C.L. 2003. Distribution of phosphorylated Smad2 identifies target tissues of TGF $\beta$ ligands in mouse development. Gene Expr. Patterns 3: 355-360.

Coucouvanis, E. and Martin, G.R. 1999. BMP signaling plays a role in visceral endoderm differentiation and cavitation in the early mouse embryo. Development 126: 535-546.

Dolci, S., Williams, D.E., Ernst, M.K., Resnick, J.L., Brannan, C.I., Lock, L.F., Lyman, S.D., Boswell, H.S., and Donovan, P.J. 1991. Requirement for mast cell growth factor for primordial germ cell survival in culture. Nature 352: 809-811.

Duncan, S.A., Manova, K., Chen, W.S., Hoodless, P., Weinstein, D.C., Bachvarova, R.F., and Darnell, J.E. 1994. Expression of transcription factor HNF-4 in the extraembryonic endoderm, gut, and nephrogenic tissue of the developing mouse embryo: HNF-4 is a marker for the primary endoderm in the implanting blastocyst. Proc. Nat1. Acad. Sci. 91: 7598-7602.

Dziadek, M. and Adamson, E. 1978. Localization and synthesis of $\alpha$ foetoprotein in post-implantation mouse embryos. J. Embryol. Exp. Morph. 43: 289-313.

Faure, S., Lee, M.A., Keller, T., ten Dijke, P., and Whitman, M. 2000. Endogenous patterns of TGF $\beta$ superfamily signaling during early Xenopus development. Development 127: 2917-2931

Fujii, M., Takeda, K., Imamura, T., Aoki, H., Sampath, T.K., Enomoto, S., Kawabata, M., Kato, M., Ichijo, H., and Miyazono, K. 1999. Roles of bone morphogenetic protein type I receptors and Smad proteins in osteoblast and chondroblast differentiation. Mol. Biol. Cell 10: 3801-3813.

Fujikura, J., Yamato, E., Yonemura, S., Hosoda, K., Masui, S., Nakao, K., Miyazaki, J., and Niwa, H. 2002. Differentiation of embryonic stem cells is induced by GATA factors. Genes \& Dev. 16: 784-789.

Ginsburg, M., Snow, M.H., and McLaren, A. 1990. Primordial germ cells in the mouse embryo during gastrulation. Development 110: 521-528.

Godin, I., Deed, R., Cooke, J., Zsebo, K., Dexter, M., and Wylie, C.C. 1991. Effects of the steel gene product on mouse primordial germ cells in culture. Nature 352: 807-809.

Goumans, M.J., Zwijsen, A., van Rooijen, M.A., Huylebroeck, 
D., Roelen, B.A., and Mummery, C.L. 1999. Transforming growth factor- $\beta$ signalling in extraembryonic mesoderm is required for yolk sac vasculogenesis in mice. Development 126: 3473-3483.

Gu, Z., Reynolds, E.M., Song, J., Lei, H., Feijen, A., Yu, L., He, W., MacLaughlin, D.T., van den Eijnden-van Raaij, J., Donahoe, P.K., et al. 1999. The type I serine/threonine kinase receptor ActRIA (ALK2) is required for gastrulation of the mouse embryo. Development 126: 2551-2561.

Gualdi, R., Bossard, P., Zheng, M., Hamada, Y., Coleman, J.R., and Zaret, K.S. 1996. Hepatic specification of the gut endoderm in vitro: Cell signaling and transcriptional control. Genes \& Dev. 10: 1670-1682.

Hayashi, K., Kobayashi, T., Umino, T., Goitsuka, R., Matsui, Y., and Kitamura, D. 2002. SMAD1 signaling is critical for initial commitment of germ cell lineage from mouse epiblast. Mech. Dev. 118: 99-109.

Inoue, K., Kohda, T., Lee, J., Ogonuki, N., Mochida, K., Noguchi, Y., Tanemura, K., Kaneko-Ishino, T., Ishino, F., and Ogura, A. 2002. Faithful expression of imprinted genes in cloned mice. Science 295: 297.

Korschynskyi, O. and ten Dijke, P. 2002. Identification and functional characterization of distinct critically important bone morphogenetic protein-specific response elements in the Id1 promoter. J. Biol. Chem. 277: 4883-4891.

Kumar, A., Novoselov, V., Celeste, A.J., Wolfman, N.M., ten Dijke, P., and Kuehn, M.R. 2001. Nodal signaling uses activin and transforming growth factor- $\beta$ receptor-regulated Smads. J. Biol. Chem. 276: 656-661.

Kuo, C.T., Morrisey, E.E., Anandappa, R., Sigrist, K., Lu, M.M., Parmacek, M.S., Soudais, C., and Leiden, J.M. 1997. GATA4 transcription factor is required for ventral morphogenesis and heart tube formation. Genes \& Dev. 11: 1048-1060.

Lawson, K.A. and Hage, W.J. 1994. Clonal analysis of the origin of primordial germ cells in the mouse. Ciba Found. Symp. 182: 68-91.

Lawson, K.A., Dunn, N.R., Roelen, B.A., Zeinstra, L.M., Davis, A.M., Wright, C.V., Korving, J.P., and Hogan, B.L. 1999. $\mathrm{Bmp} 4$ is required for the generation of primordial germ cells in the mouse embryo. Genes \& Dev. 13: 424-436.

Levenberg, S., Golub, J.S., Amit, M., Itskovitz-Eldor, J., and Langer, R. 2002. Endothelial cells derived from human embryonic stem cells. Proc. Natl. Acad. Sci. 99: 4391-4396.

Li, Y., Lemaire, P., and Behringer, R.R. 1997. Esx1, a novel X chromosome-linked homeobox gene expressed in mouse extraembryonic tissues and male germ cells. Dev. Biol. 188: 85-95.

Liu, F., Ventura, F., Doody, J., and Massagué, J. 1995. Human type II receptor for bone morphogenic proteins (BMPs): Extension of the two-kinase receptor model to the BMPs. Mol. Cell Biol. 15: 3479-3486.

Matzuk, M.M., Kumar, T.R., and Bradley, A. 1995. Different phenotypes for mice deficient in either activins or activin receptor type II. Nature 374: 356-360.

McLaren, A. 2003. Primordial germ cells in the mouse. Dev. Biol. 262: 1-15.

Mishina, Y., Suzuki, A., Ueno, N., and Behringer, R.R. 1995. Bmpr encodes a type I bone morphogenetic protein receptor that is essential for gastrulation during mouse embryogenesis. Genes \& Dev. 9: 3027-3037.

Mishina, Y., Crombie, R., Bradley, A., and Behringer, R.R. 1999. Multiple roles for activin-like kinase-2 signaling during mouse embryogenesis. Dev. Biol. 213: 314-326.

Monteiro, R.M., Chuva de Sousa Lopes, S.M., Korchynskyi, O., ten Dijke, P., and Mummery, C.L. 2004. Spatio-temporal activation of Smad1 and Smad5 in vivo: Monitoring transcrip- tional activity of Smad proteins. J. Cell. Sci. (in press).

Oh, S.P. and Li, E. 1997. The signaling pathway mediated by the type IIB activin receptor controls axial patterning and lateral asymmetry in the mouse. Genes \& Dev. 11: 1812-1826.

Oh, S.P., Seki, T., Goss, K.A., Imamura, T., Yi, Y., Donahoe, P.K., Li, L., Miyazono, K., ten Dijke, P., Kim, S., et al. 2000. Activin receptor-like kinase 1 modulates transforming growth factor- $\beta 1$ signaling in the regulation of angiogenesis. Proc. Natl. Acad. Sci. 97: 2626-2631.

Persson, U., Izumi, H., Souchelnytskyi, S., Itoh, S., Grimsby, S., Engström, U., Heldin, C.H., Funa, K., and ten Dijke, P. 1998. The L45 loop in type I receptors for TGF $\beta$ family members is a critical determinant in specifying Smad isoform activation. FEBS Lett. 434: 83-87.

Pesce, M., Gioia Klinger, F., and De Felici, M. 2002. Derivation in culture of primordial germ cells from cells of the mouse epiblast: Phenotypic induction and growth control by BMP4 signalling. Mech. Dev. 112: 15-24.

Qi, X., Li, T.G., Hao, J., Hu, J., Wang, J., Simmons, H., Miura, S., Mishina, Y., and Zhao, G.Q. 2004. BMP4 supports self-renewal of embryonic stem cells by inhibiting mitogen-activated protein kinase pathways. Proc. Natl. Acad. Sci. 101: 6027-6032.

Roelen, B.A., Lin, H.Y., Knežević, V., Freund, E., and Mummery, C.L. 1994. Expression of TGF $\beta$ s and their receptors during implantation and organogenesis of the mouse embryo. Dev. Biol. 166: 716-728.

Roelen, B.A., Goumans, M.J., van Rooijen, M.A., and Mummery, C.L. 1997a. Differential expression of BMP receptors in early mouse development. Int. J. Dev. Biol. 41: 541-549.

Roelen, B.A., van Rooijen, M.A., and Mummery, C.L. 1997 b. Expression of ALK-1, a type 1 serine/threonine kinase receptor, coincides with sites of vasculogenesis and angiogenesis in early mouse development. Dev. Dyn. 209: 418-430.

Saitou, M., Barton, S.C., and Surani, M.A. 2002. A molecular programme for the specification of germ cell fate in mice. Nature 418: 293-300.

Sato, M., Kimura, T., Kurokawa, K., Fujita, Y., Abe, K., Masuhara, M., Yasunaga, T., Ryo, A., Yamamoto, M., and Nakano, T. 2002. Identification of PGC7, a new gene expressed specifically in preimplantation embryos and germ cells. Mech. Dev. 113: 91-94.

Shi, Y. and Massagué, J. 2003. Mechanisms of TGF $\beta$ signaling from cell membrane to the nucleus. Cell 113: 685-700.

Song, J., Oh, S.P., Schrewe, H., Nomura, M., Lei, H., Okano, M., Gridley, T., and Li, E. 1999. The type II activin receptors are essential for egg cylinder growth, gastrulation and rostral head development in mice. Dev. Biol. 213: 157-169.

Tam, P.P. and Zhou, S.X. 1996. The allocation of epiblast cells to ectodermal and germ-line lineages is influenced by the position of the cells in the gastrulating mouse embryo. Dev. Biol. 178: 124-132.

Tanaka, S.S. and Matsui, Y. 2002. Developmentally regulated expression of mil-1 and mil-2, mouse interferon-induced transmembrane protein like genes, during formation and differentiation of primordial germ cells. Mech. Dev. 119 Suppl. 1: S261-S267.

Toyooka, Y., Tsunekawa, N., Akasu, R., and Noce, T. 2003. Embryonic stem cells can form germ cells in vitro. Proc. Nat1. Acad. Sci. 100: 11457-11462.

Tremblay, K.D., Dunn, N.R., and Robertson, E.J. 2001. Mouse embryos lacking Smad1 signals display defects in extra-embryonic tissues and germ cell formation. Development 128: 3609-3621.

Watt, A.J., Jones, E.A., Ure, J.M., Peddie, D., Wilson, D.I., and Forrester, L.M. 2001. A gene trap integration provides an 
early in situ marker for hepatic specification of the foregut endoderm. Mech. Dev. 100: 205-215.

Winnier, G., Blessing, M., Labosky, P.A., and Hogan, B.L. 1995. Bone morphogenetic protein-4 is required for mesoderm formation and patterning in the mouse. Genes \& Dev. 9: 21052116.

Yeom, Y.I., Fuhrmann, G., Ovitt, C.E., Brehm, A., Ohbo, K., Gross, M., Hubner, K., and Schöler, H.R. 1996. Germline regulatory element of Oct-4 specific for the totipotent cycle of embryonal cells. Development 122: 881-894.

Yi, S.E., Daluiski, A., Pederson, R., Rosen, V., and Lyons, K.M. 2000. The type I BMP receptor BMPRIB is required for chondrogenesis in the mouse limb. Development 127: 621-630.

Ying, Y. and Zhao, G.Q. 2001. Cooperation of endoderm-derived BMP2 and extraembryonic ectoderm-derived BMP4 in primordial germ cell generation in the mouse. Dev. Biol. 232: 484-492.

Ying, Y., Liu, X.M., Marble, A., Lawson, K.A., and Zhao, G.Q. 2000. Requirement of Bmp8b for the generation of primordial germ cells in the mouse. Mol. Endocrinol. 14: 10531063.

Ying, Y., Qi, X., and Zhao, G.Q. 2001. Induction of primordial germ cells from murine epiblasts by synergistic action of BMP4 and BMP8b signaling pathways. Proc. Natl. Acad. Sci. 98: 7858-7862.

Yoshimizu, T., Obinata, M., and Matsui, Y. 2001. Stage-specific tissue and cell interactions play key roles in mouse germ cell specification. Development 128: 481-490. 


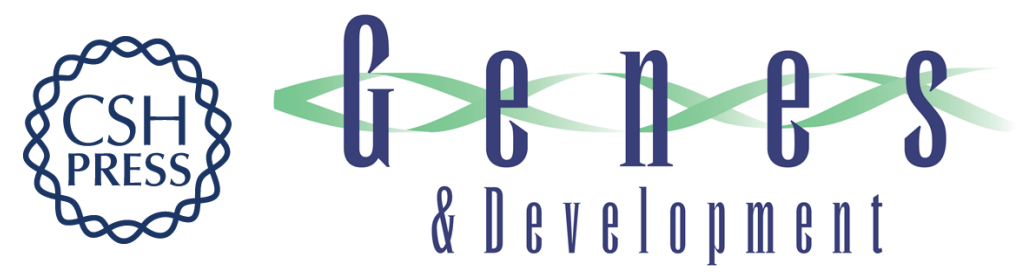

\section{BMP signaling mediated by ALK2 in the visceral endoderm is necessary for the generation of primordial germ cells in the mouse embryo}

Susana M. Chuva de Sousa Lopes, Bernard A.J. Roelen, Rui M. Monteiro, et al.

Genes Dev. 2004, 18:

Access the most recent version at doi:10.1101/gad.294004

References This article cites 58 articles, 4 of which can be accessed free at:

http://genesdev.cshlp.org/content/18/15/1838.full.html\#ref-list-1

License

Email Alerting

Receive free email alerts when new articles cite this article - sign up in the box at the top

Service

right corner of the article or click here.

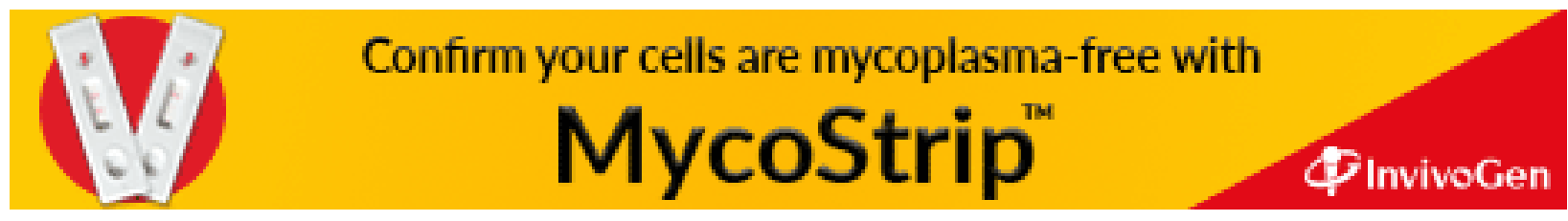

